\title{
Impact of political costs on company benefits in the institutions with high free cash flow and low growth opportunity: Evidence from Tehran Stock Exchange
}

\author{
Mohammad Pasandidehfar $^{\mathrm{a}}$, Shadi Shahverdiani ${ }^{\mathrm{b} *}$ and Mohsen Hashemi Gohar ${ }^{\mathrm{b}}$
}

${ }^{a}$ Master student of accounting . Department of Accounting, Shahr-e-Qods Branch, Islamic Azad University, Tehran, Iran ${ }^{b}$ Assistant professor. Department of Financial Management, Shahr-e-Qods Branch, Islamic Azad University, Tehran, Iran

\section{H R O N I C L E}

Article history:

Received October 5, 2015

Received in revised format

December 162015

Accepted February 22016

Available online

February 32016

Keywords:

Political costs

Free cash flow

Growth opportunities

Politically considerations

\begin{abstract}
A B S T R A C T
The political costs, bonuses paid to managers, how to use the growth opportunities obtained and their effects on the profitability of companies are the issues that have always been a major of corporations' concerns. Company exposure to political decisions, its costs and effects on the company's cash flow is very important. Hence, understanding the relationship between variables in a company and how they influence on each other helps management decisions for better opportunities and reduction in political costs, increase cash flow and ultimately increase the profitability of the firms. This survey studies the relationship between the impact of political costs on companies with high free cash flow and low growth opportunity. In this survey, company's assets, sales, income and number of employees are estimated. Then the indexes related to these costs are evaluated based on the tax component, the cost of the sports, personnel costs and relationships among them. Pearson correlation coefficient, regression coefficients and analysis of variance have been used to examine the hypotheses of the survey. The results show that the political cost, high free cash flow and low growth opportunity had negative correlations with each other. In other words, there was a negative relationship between profit and political costs in companies with high free cash flow and low growth opportunity. Moreover, high free cash flow and low growth opportunities had significant effect on the relationship between political costs and benefits in companies listed in Tehran Stock Exchange.
\end{abstract}

\section{Introduction}

During the past few years, there have been several studies indicating that the size of the company and the level of corporate profits in Iran had some impacts on the political views of those companies. However, it seems that the political cost is different in various industries and type of industry influences the political views and expenses (Wong, 1988). This is very crucial because the assumptions about the relations between type of industry and political costs can create motivation for managing earnings in various industries. Although most managers of Iranian companies active in the political environment 
affecting corporate and political costs are not aware of the definition and classification of expenditures (Watts, 1977; Shaffer \& Russo, 1998). According to agency theory, the organization is the set of conventions, the entity of a business is based on its contracts and these contracts can be written or unwritten (Jensen, 1990).

The primary objective of this survey is on the presence or absence of political costs and their relationships with type of industry. The survey also aims on awareness for all managers and activists on the stock exchange, accounting and auditing professionals. Consequently, shareholders, corporate executives, financial analysts, educational institutions and students can use the results of this research in comparative studies and other financial investigations. This research helps us understand the importance of disclosure of political costs and its relation to accounting and financial variables and take steps to improve the data loading in financial statements and thereby helps for decision making process of managers, shareholders and other users of the financial statements.

\section{Theoretical framework and literature review}

According to Milne (2002), "the political cost hypothesis postulates that a firm operates in society based on explicit and implicit contracts with individuals and groups". These groups include government, employees, consumers, special interest groups, and the public in general. The political cost hypothesis indicates that the bigger the political costs of the company, the more likely management to implement accounting policies to defer reported earnings from current period to future periods. This hypothesis brings politics into the option of accounting policies. Highly profitable firms absorb media and consumer attention, which increases in taxes and other regulations (Scott, 2014).

Political costs are associated with essentials for business continuity and life, according to legal requirements and customary and economic environment (Bushman \& Piotroski, 2006). These costs will be imposed on firms through legal actions and regulatory approvals or by political pressure. For instance, tax, pension insurance, the expenses of grants to individuals, corporates and institutions, contribute to the sport, export customs duties, the expenses of environmental protection, space development training costs, payments to trade unions and other informal authorities are considered as political costs (Daley \& Vigeland, 1983).

Information about the cash flows of an entity is useful in providing users of financial statements with a basis to evaluate the capability of an entity to produce cash and cash equivalents and the necessity of the entity to utilize those cash flows. The economic decisions taken by users need an evaluation of the capability of an entity to produce cash and cash equivalents and the timing and certainty of their generation. The objective of such standard is the provision of information about the historical changes in cash and cash equivalents of an entity by tools of a statement of cash flow which classifies cash flows during the period from operating, investing and financing activities (IAS 7).

Free cash flow, including measures based on accounting data that can be used to measure performance and demonstrates firm's cash after doing the necessary funding for the maintenance or development of assets at its disposal (Jensen, 1986). According to the International Accounting Standard (IAS 7), an entity presents its cash flows from operating, investing and financing activities in a manner which is most appropriate to its business. Classification by activity provides information that allows users to evaluate the effect of those activities on the financial position of the entity and the amount of its cash and cash equivalents. This information may also be utilized to evaluate the relationships among those activities.

Earnings management is associated with the use of discretionary accounting accruals to manipulate reported earnings figures (Schipper, 1989, pp. 92-93; Jones, 1991, p. 206). Watts and Zimmerman (1986, pp. 230-231) argue that, because corporations may vulnerable to wealth-extracting political transfers in the form of legislation and/or regulation, firms may use earnings management to decrease net income in periods of increased political sensitivity. A number of recent studies provide evidences 
of earnings management in periods of increased political exposure (Jones, 1991; Cahan, 1992; Han \& Wang, 1998). However, these studies assume that all sample firms are equally influenced by the political costs. In contrast, and more closely related to our investigation, Cahan et al. (1997, p. 46) argue that levels of political exposure likely vary across firms, and as such, the magnitude of earnings management should be expected to show cross-sectional variation as well. To test this hypothesis, Cahan et al. (1997) examined the response of 43 chemical companies to legislation associated with the establishment of the superfund laws dealing with the cleanup of hazardous waste sites. They reported significant negative discretionary accruals for their overall sample for 1979 . However, the results for differences in the cross-sectional magnitude of these discretionary accruals and their relation to political costs were mixed. In addition, because, as noted by Cahan et al. (1997, p. 46), corporations have incentives not to reduce reported income, one may expect that firms with other strategic processes for dealing with political exposure in place will face a lower magnitude of earnings manipulation in response to regulatory threats.

As NASDAQ defines, growth opportunity is an opportunity to invest in profitable projects. Growth opportunity is an investment or project that has the potential to grow significantly, leading to a profit for the investor. New investments are often presented to potential investors as growth opportunities. ${ }^{1}$ According to Jensen's theory (1986), the companies that have high investment opportunities are expected to have less free cash flow, because as well as the investment opportunities (potential) increase, much of the surplus funds will be used to take advantage of potential growth opportunities.

\section{Methodology}

In this survey, we study the relationship between political cost and profitability as well as the relationship between free cash flow and growth opportunities on selected firms on Tehran Stock Exchange. The sample of this study is 223 selected companies from 530 companies accepted in the Tehran Stock Exchange from 2008 to 2014. The total number of observations in these 223 companies was over 7 years or 1561 observations.

\subsection{Hypotheses}

$\mathrm{H}_{1}$ : The political costs have significant impacts on profits of firms listed on the Tehran Stock Exchange.

$\mathrm{H}_{2}$ : Higher free cash flow and growth opportunities reduces the effects on the relationship between political costs and profits of firms listed in the Tehran Stock Exchange.

The independent variable in this study is political costs. Benefit is the dependent variable and high free cash flow and low growth opportunities as well as moderating variable are also considered as other variables of the proposed study. Data analysis and descriptive statistics such as mean, median and standard deviation, skewness and kurtosis index distribution have been considered to examine the hypotheses of this study.

The implementation of Kolmogorov-Smirnov test yields a significance value of 0.000 , which means the data were not normally distributed. One of the most common methods for normalizing the data is to use the conversion. Especially in cases where data distribution is skewed to the right, Logarithmic Transformation, is very appropriate. According to the obtained logarithmic values, this variable is more than 0.05 for most data. Therefore, predicted logarithmic distribution for these variables, skewness and kurtosis parameters close to zero, is normal. Central indexes, including mean, median and dispersion measures such as standard deviation, kurtosis and skewness for different variables are presented in Table 1 as follows,

\footnotetext{
1 - http://www.nasdaq.com /investing/glossary/g/growth-opportunity
} 
Table 1

Descriptive Statistics for different variables

\begin{tabular}{lcccccccc}
\hline Variables & Observations & Mean & Median & standard deviation & Kurtosi & Skewnes & Min & Max \\
\hline E & 1561 & 6502.79 & 887.75 & 15245.05 & 5.18 & 36.87 & 5.43 & 168752.91 \\
Ln(E) & 1561 & 6.95 & 6.79 & 2.08 & 0.10 & -0.77 & 1.69 & 12.04 \\
Ln (PC) & 1557 & 12.11 & 12.21 & 1.50 & -0.42 & 1.06 & 4.61 & 16.65 \\
FCF $_{\text {hish }}$ Growth & 1553 & 3.47 & 0.00 & 5.63 & 1.06 & -0.80 & 0.00 & 16.18 \\
\hline
\end{tabular}

If the mean and median of the variables are close to each other, data distribution is symmetric (Kurtosis and Skewness of a normal distribution tend to zero).

Analysis of the integrated data has been accomplished using a panel analysis. One of the main topics discussed at the panel analysis is to determin the value of the intercept and determine the fitness of the model without intercept or intercept. In the case that the model is intercept, the next question will be that designing the model with fixed effects or random effects. To determine the suitability of model with fixed or random effects, Limer (Chow) test and Hausman test have been used.

Table 2

Chow test to select the appropriate model

\begin{tabular}{lccc}
\hline Test of effects & t-value & Degree of freedom & Sig. \\
\hline F-value & 2.287 & $(221,1321)$ & 0.000 \\
Chi-Square & 532.764 & 222 & 0.000 \\
\hline
\end{tabular}

The statistical observation are meaningful when the level of significance is five percent. Therefore, the null hypothesis is rejected at the $95 \%$ confidence and the model is appropriate in fixed effects.

Table 3

The results of Hausman test

\begin{tabular}{lccc}
\hline Result & Chi-Square & Degree of freedom & Sig. \\
\hline Model with fixed effects & 162.090 & 4 & 0.000 \\
\hline
\end{tabular}

The statistical observation are meaningful when the level of significance is five percent. Therefore, the null hypothesis is rejected at the $95 \%$ confidence and the model is appropriate in fixed effects. Table 4 presents the results of the regression model.

Table 4

The summary of regression model

\begin{tabular}{lcccl}
\hline Parameters & Coefficients & t-value & Sig. & Result \\
\hline Fixed value & 1.16 & 2.16 & 0.031 & Significant and positive \\
FCF $_{\text {high }}$ Growth & 0.48 & 14.49 & 0.000 & Significant and positive \\
$\mathrm{pc} \times \mathrm{E}_{i t}$ & -0.03 & -2.76 & 0.006 & Significant and positive \\
\hline
\end{tabular}

F-value $=5.81(0.000)$ Adjusted R-Square $=0.51$ Durbin-Watson $=2.32$

The model in Table 4 has been estimated with fixed effects. Significance probability of $F$ is equal to 0.000 , which is less than 5\%. Therefore, the null hypothesis is rejected at the $95 \%$ confidence level and the relationship is linear. The coefficient of determination is equal to 0.51 , which means that about $51 \%$ of the variance is explained by the independent variables and control. The Durbin-Watson statistic is equal to 2.32. Values close to 2 indicate lack of correlation in residuals, which confirms another regression assumption. According to the results, political cost has a significant impact on profits of companies listed on the Stock Exchange in Tehran but it has negative impact $(\beta=-0.03, \mathrm{t}$-value $=-2.76$ $($ Sig. $=0.006))$. In addition, high free cash flow and low growth opportunities have significant effect 
on the relationship between political costs and benefits in companies listed in Tehran Stock Exchange and thus the relationship intensified with this impact $(\beta=0.48$, t-value $=14.49($ Sig. $=0.000))$.

Based on the results obtained from the hypotheses, the political cost influences on profit in companies with high free cash flow and low growth in the Tehran Stock Exchange. In addition, according to the results of the first hypothesis, the impact has been negative, so the relationship between political costs and earnings in companies with high free cash flow and low growth relationship is declining. According to the results of the study hypothesis, high free cash flow and low growth opportunity influenced on the political costs.

\section{Conclusion and suggestions}

Due to the positive coefficient obtained from the results of this test, we have confirmed the first hypothesis, which indicates that political cost impact on profit in companies with high free cash flow and low growth in the Tehran Stock Exchange and the effect was negative. Therefore, the relationship between political costs and earnings in companies with high free cash flow and low growth is declining relationship.

It appears that people may pay more attention to the political cost and due to its negative impact on the profitability of the companies, managers have to possibly apply appropriate tools and policies in order to reduce these costs.

Secondly, according to the result of the second hypothesis it can be said that any increase in the free cash flow and low growth opportunity, will increase the negative impact on corporate profits. In order to prevent negative effects present verb root political costs on corporate profits, it is recommended that controls carried out on company's excursions free cash, so that existence of high cash flow, not lead managers and their policies towards the political costs. Obviously, cash flows can be used in line with other goals of company.

This paper can be extended in different ways. First, the study was not accomplished by clustering Tehran Stock Exchange into various sectors. We believe the results of this study could be different when one applies the regression model in different sectors, separately. We leave this as a future research for interested researchers as future work.

\section{Acknowledgement}

The authors would like to thank the anonymous referees for constructive comments on earlier version of this work. We are also delighted for the support provided by officials of Tehran Stock Exchange and their insights, which guided this research study into right direction.

\section{References}

Bushman, R. M., \& Piotroski, J. D. (2006). Financial reporting incentives for conservative accounting: The influence of legal and political institutions.Journal of Accounting and Economics, 42(1), 107-148.

Cahan, S. F. (1992). The effect of antitrust investigations on discretionary accruals: A refined test of the political-cost hypothesis. Accounting Review, 67(1), 77-95.

Cahan, S. F., Chavis, B. M., \& Elmendorf, R. G. (1997). Earnings management of chemical firms in response to political costs from environmental legislation. Journal of Accounting, Auditing \& Finance, 12(1), 37-65.

Daley, L. A., \& Vigeland, R. L. (1983). The effects of debt covenants and political costs on the choice of accounting methods: The case of accounting for R\&D costs. Journal of accounting and economics, 5, 195211.

Han, J. C., \& Wang, S. W. (1998). Political costs and earnings management of oil companies during the 1990 Persian Gulf crisis. Accounting Review, 73(1), 103-117. 
Jensen, M. C. (1986). Agency cost of free cash flow, corporate finance, and takeovers. Corporate Finance, and Takeovers. American Economic Review,76(2).

Jones, J. J. (1991). Earnings management during import relief investigations.Journal of Accounting Research, 29(2), 193-228.

Milne, M. J. (2002). Positive accounting theory, political costs and social disclosure analyses: A critical look. Critical Perspectives on Accounting,13(3), 369-395.

Shaffer, B., \& Russo, M. V. (1998). Political strategies and industry environments. Research in corporate social performance and policy, 15, 3-15.

Schipper, K. (1989). Commentary on earnings management. Accounting Horizons, 3(4), 91-102.

Scott, W. R. (2014). Financial accounting theory. Pearson Education Canada.

Watts, R. L. (1977). Corporate financial statements, a product of the market and political processes. Australian journal of management, 2(1), 53-75.

Watts, R. L., \& Zimmerman, J. L. (1986). Positive accounting theory.

Wong, J. (1988). Political costs and an intraperiod accounting choice for export tax credits. Journal of Accounting and Economics, 10(1), 37-51. 